\title{
Biochemical Basis of Resistance to Turcicum Leaf Blight of Maize caused by Exserohilum turcicum (Pass.) Leonard and Suggs
}

\author{
E. Jagadeesh*, K. T. Pandurange Gowda and K. C. Narayana Swamy \\ ${ }^{1}$ Quality control cell, FCI Campus, Dighaghat. Patna, India \\ ${ }^{2}$ College of Agriculture, Mandya, india \\ ${ }^{3}$ Department of Agricultural Entomology, University of Agricultural and \\ Horticultural Sciences, Shimoga, India \\ *Corresponding author
}

A B S T R A C T

\begin{tabular}{l} 
K e y w o r d s \\
$\begin{array}{l}\text { Exserohilum } \\
\text { turcicum, } \\
\text { Phenols,Tanins,Sug } \\
\text { ars,Resistance }\end{array}$ \\
\hline Article Info \\
$\begin{array}{l}\text { Accepted: } \\
\text { 15 February } 2020 \\
\text { Available Online: } \\
10 \text { March } 2020\end{array}$ \\
\hline
\end{tabular}

Studies on Biochemical basis of resistance to turcicum leaf blight of maize caused by Exserohilum turcicum revealed that the total sugar content was more in resistant genotypes Nithyashree and Hema as campared with susceptible genotypes, 219J and CM-202 when estimated following Nelson's modification of Somogyi's method. It was evident that total phenol content through folin-ciocalteau reagent method, Lowry method of protein estimation total protein content and Estimation of tannins by vanillin hydrochloride method revealed that total phenol, protein and tannin contents were more in resistant genotype than in susceptible genotypes and there was significant increase in both the genotypes with severity of disease respectively.

\section{Introduction}

Maize (Zea mays L.) is known as "King of crops" and "Miracle crop or Queen of cereals" in view of its several uses. It is being grown both for seed and fodder purpose. The maize is grown in many parts of the world for its immense potentiality both for adoption and nutritive value but increase in area, production and productivity creates very favorable condition for several foliar and stalk rot diseases (Payak and Sharma, 1980). The
Northern leaf blight caused by Exserohilum turcicum (Pass.) affecting maize causes more than 50 per cent loss in grain yield was reported in USA (Robert, 1953; Raymundo and Hooker, 1981).

In India, the turcicum leaf blight is prevalent in almost all the maize growing areas. Severe losses in grain yield due to epiphytotics have been reported in several parts of India and these losses vary from 25 to 90 per cent depending upon the severity of the disease 
(Chenulu and Hora, 1962; Jha, 1993). The turcicum leaf blight is an important fungal foliar disease affecting several cultivated hybrids and composites in karnataka. The disease has attained economic status in the state. However, not much systematic research work being carried out on resistant sources and management of important disease of maize. Hence biochemical analysis of resistant and susceptible varities should be done to get a comprehensive information on disease development stratergies these studies play a vital role in developing resistant varities.

\section{Materials and Methods}

\section{Extraction of plant tissues in alcohol}

Estimation of metabolites requires their complete extraction from the tissues. The activities of the enzymes which synthesize and utilize them need to be stopped at once to get reliable values. Plant constituents possess different solvents. Though, water is the universal solvent, it does not penetrate the tissue quickly enough to stop the enzymatic activity. In this context alcohol especially hot alcohol was the choicest solvent for the extraction.

\section{Reagent}

Distilled ethanol (80\%)

\section{Procedure}

One gram of the tissue was weighed and made into small pieces and plunged immediately in boiling alcohol. Then, it was cooled and passed through double layered muslin cloth. The pieces of the tissue was ground thoroughly in a morter with pestle with hot alcohol. Again it was passed through muslin cloth. The above procedure was repeated. The filtrate were pooled and filtered through Whatman No. 41 filter paper and made up to ten $\mathrm{ml}$ volume with alcohol. Then the extract was stored in a refrigerator at $4{ }^{\circ} \mathrm{C}$. This alcoholic extract of the tissue contains reducing sugars, non-reducing sugars, phenols, chlorophylls etc., whereas the residues contain proteins which were used for further analysis. Heavy metal salts are therefore employed to tackle the problem excess of which is precipitated by disodium hydrogen phosphate.

\section{Reagents}

Saturated solution of neutral lead acetate and saturated solution of disodium hydrogen phosphate.

\section{Procedure}

Two ml of saturated lead acetate solution was added drop wise to $10 \mathrm{ml}$ of the coloured alcoholic extract with three $\mathrm{ml}$ of saturated solution of disodium hydrogen phosphate till the precipitation is completed. The above solutions were mixed thoroughly and kept for overnight. Further, it was filtered through Whatman No. 41 filter paper and made up to $15 \mathrm{ml}$ volume with 80 per cent alcohol and stored in a refrigerator at $4{ }^{\circ} \mathrm{C}$.

\section{Estimation of phenol}

Plant tissues contain a large number of phenolic compounds. The most important of which are simple phenols, coumarine, most flavonoids, certain amino acids,prosthetic groups, some enzymes, plant pigments and complex derivatives such as lignins. Phenolic substances are known to participate in a number of physiological processes which are essential for growth and development, such as oxidation reduction reactions, lignifications and stimulation as well as inhibition of auxin activity. Phenolic compounds occur in a variety of simple and complex forms. Simple 
phenols such as cinnamic, coumarine, caffeic, protocatechuic, chlorogenic and quinic acid exhibit anti-microbial activities.

The total phenols present in plant samples was estimated by following folin-ciocalteau reagent method.

\section{Reagents}

1. Folin - ciocalteau reagent (FCR, 1\%)

2. Sodium carbonate $(2 \%)$

\section{Procedure}

One ml of each alcoholic extract was taken in a test tube to which one $\mathrm{ml}$ of Folin ciocalteau reagent was added followed by two $\mathrm{ml}$ of sodium carbonate solution $(2 \%)$. The tubes were shaken well and heated in a hot water bath for exactly one minute and then cooled under running tap water. The content developed was diluted to $25 \mathrm{ml}$ with distilled water and its absorbance was read at $650 \mathrm{~nm}$ in spectrophotometer. The amount of phenols present in sample was calculated from a standard curve prepared from catechol.

\section{Estimation of proteins}

Protein estimation was done by the following the procedure of Lowry method of protein estimation.

Bovine serum albumin was used as the standard.

\section{Reagents}

Solution A : $2 \%$ sodium carbonate in $0.1 \mathrm{~N}$ $\mathrm{NaOH}$ solution.

Solution B : $1 \%$ sodium potassium tartarate.

Solution C : $0.5 \%$ copper sulfate.

Solutions A, B and C in 100:1:1 proportion was mixed just before use.

Folin ciocalteau reagent (FCR) diluted to $1: 1$ before use.

\section{Procedure}

The samples were diluted to $100 \mu \mathrm{g}$ protein concentration per $\mathrm{ml}$ and known aliquots of the sample were made up to $1 \mathrm{ml}$ with distilled water. To this $5 \mathrm{ml}$ of solution $\mathrm{C}$ was added and mixed well. After $10 \mathrm{~min} 0.5 \mathrm{ml}$ of FCR was added and mixed well. The colour developed after $30 \mathrm{~min}$ was measured at $660 \mathrm{~nm}$ against a reagent blank.

\section{Estimation of sugars}

Sugars are precursors for synthesis of phenols, phytoalexins, lignin and callose. Hence, they play an important role in defense mechanism of plants. Reviews on changes in sugar content during pathogenesis has been reviewed here under. Horsfall and Dimond (1957) assigned a major role for sugars in disease resistance. They classified the diseases as high sugar diseases and low sugar diseases. Low sugar diseases occur severely when host sugar content is low and high sugar diseases occur when host sugar content is high. In general, infection by some pathogens bring about lot of changes in respiratory pathway and photosynthesis which are vital processes in plants. This lead to wide fluctuation in sugar contents (Farkas and Kiraly, 1962; Kuc, 1966 and Klement and Goodman 1967). The intermediates of calvins reductive pentose (C3) pathway of $\mathrm{CO} 2$ fixation potentially can interconnect with other pathways of carbohydrate metabolism. The pathogen which disturbs photosynthetic activity either by more injury to the photosynthetic organ or by directly affecting metabolic activity, certainly brings about changes in sugar content of plants.

\section{Estimation of sugars}

The reducing sugar was estimated following Nelson's modification of Somogyi's method. 


\section{Reagents}

\section{Alkaline copper reagent}

\section{Solution a}

Twentyfive gram of anhydrous sodium carbonate, $25 \mathrm{~g}$ of sodium potassium tartarate, $20 \mathrm{~g}$ of sodium bicarbonate and $200 \mathrm{~g}$ of sodium sulphate were dissolved in about 800 $\mathrm{ml}$ of distilled water and final volume was made up to one litre.

\section{Solution b}

Fifteen grams of copper sulphate was dissolved in distilled water and one or two drops of concentrated sulphuric acid was added and made up to $100 \mathrm{ml}$ with distilled water. Solution $a$ and $b$ was mixed in $24: 1$ $(\mathrm{v} / \mathrm{v})$ proportion just before use.

\section{Arsenomolybdate reagent}

1. $25 \mathrm{~g}$ of ammonium molybdate was dissolved in $450 \mathrm{ml}$ of distilled water. $21 \mathrm{ml}$ of concentrated sulphuric acid was added and mixed with above solution. 2. $3 \mathrm{~g}$ of sodium orthoarsenate was dissolved in $25 \mathrm{ml}$ of distilled water. These above two solutions were mixed with stirring and placed in an incubator at $37^{\circ} \mathrm{C}$ for $24-48 \mathrm{hr}$. The reagent was stored in brown bottle.

\section{Procedure}

$1 \mathrm{ml}$ of each sample (alcoholic extract) was pipetted to a test tube. To each $1 \mathrm{ml}$ of extract $1 \mathrm{ml}$ of mixture of solution $\mathrm{a}$ and $\mathrm{b}$ was added. The test tubes were heated on a hot water bath for $20 \mathrm{~min}$. The tubes were then cooled under running tap water. After cooling $1 \mathrm{ml}$ of arsenomolybdate reagent was added. The above solution was diluted to $15 \mathrm{ml}$ after $15 \mathrm{~min}$. The absorbance of the solution was measured in spectrophotometer at $510 \mathrm{~nm}$.
The amount of reducing sugars

\section{Tannin}

Estimation of tannins was done by adopting vanillin hydrochloride method,

\section{Preparation of reagents}

Vanillin of hydrochloride reagent: The equal volume of $8 \%$ hydro chloric acid was mixed in ethanol (a)and $4 \%$ vanillin in methanol ' $b$ '. The solution a \& b were mixed just before use.

Catechin stock standard solution; Hunderd milligram of catechin was dissolved in $100 \mathrm{ml}$ of methanol,

Working of standerd was prepared by diluting the above stock solution ten times, 10 $\mathrm{ml}$ to $100 \mathrm{ml}(100 \mathrm{ug} / \mathrm{ml})$.

\section{Procedure}

One $\mathrm{ml}$ of extracts of leaf was pipette out in test tubes, Five $\mathrm{ml}$ of vanillin hydrochloride reagent was added quickly and mixed thoroughly mixed it and blank was prepared with vanillin hydrochloride reagent alone, The absorbance was measured in spectrophotometer at $500 \mathrm{~nm}$ after $20 \mathrm{~min}$, and standard graph was prepared with 20-100 ug catechin using the diluted stock solution.

\section{Calculation}

The amount of catechin i,e tannin in the sample as per values was calculated using the standerd graph and the results were expressed in catechin equivalent.

\section{Results and Discussion}

Infection by pathogen brings about lot of changes in respiratory pathway and photosynthesis which are the important vital processes taking place inside the plant leading 
to wider fluctuations in biochemical components. This inturn alters the resistance of the host. Some studies on biochemical components in maize genotypes were carried out as described in material and methods and the results are presented here under.

\section{Total sugar}

This experiment shows that the total sugar content of maize genotypes varies significantly among the susceptible and resistant genotypes along with crop growth stages and disease progress (TABLE -1). The higher amount of total sugars were noticed in resistant genotypes as compared with the susceptible genotyopes and as the severity of diseases increase the total sugar content of all genotypes were drastically reduces to lower rate. Out of resistant genotypes. The genotype Nithyashree shows higher amount of total sugars i,e, $(18.6 \mathrm{mg} / \mathrm{dry} \quad \mathrm{wt})$ at $30 \mathrm{DAS}$ followed by Hema Containing $(16.1 \mathrm{mg} / \mathrm{dry}$ wt) and at 90 DAS the maximum reduction in total sugar content was noticed in both the genotypes where as Hema Shows 28\% of reduction as compared with Nithyashree $25.4 \%$. Among susceptible genotypes at 30DAS maximum total sugar content was observed in CM-202( $6.6 \mathrm{mg} / \mathrm{dry} \mathrm{wt}$ ) and followed by $219 \mathrm{~J}(5.2 \mathrm{mg} / \mathrm{dry} \mathrm{wt})$ And these genotypes shows minimum reduction of (5.9 $\mathrm{mg} / \mathrm{dry} \mathrm{wt})$ in case of CM-202 and (4.5 $\mathrm{mg} / \mathrm{dry} w \mathrm{w}$ ) in case of $219 \mathrm{~J}$ at 60DAS. These genotypes shows maximum reduction of total sugars at 90DAS i,e, $(4.1 \mathrm{mg} / \mathrm{dry} \mathrm{wt})$ in case of CM-202 followed by 219J (3.5mg/dry wt) shows where as the mean total sugars was significantly more in resistant genotypes than in susceptible genotypes.

\section{Total proteins}

The both resistant and susceptible genotypes shows significant difference in total Protein content with respect to different stages of crop growth and with severity of disease (TABLE -2). At 30 DAS the total protein content was more in resistant genotype i,e, Hema (12.3 $\mathrm{mg} /$ dry wt) followed by Nithyashree (11.1 mg/dry wt) And among susceptible genotypes the maximum protein content was observed in 219J (9.4 mg/dry wt) followed by CM-202 $(8.3 \mathrm{mg} / \mathrm{dry} \mathrm{wt})$ but there was significant increase over total protein content among the genotypes with respect to increase in desease severity at 60 and 90 DAS. In susceptible genotypes the increase in total protein content was significantly less in duration of 60 to 90 DAS with respect to disease progress as compared with resistant genotypes. The total protein content was maximum in Hema (18.5 mg/dry wt) ) followed by Nithyashree (17.5mg/dry wt) when observed at 90DAS and. Among all the genotypes the genotype Hema $(15.3 \mathrm{mg} / \mathrm{dry}$ wt) shows maximum mean protein content and the genotype CM-202 ( $8.73 \mathrm{mg} / \mathrm{dry} w \mathrm{wt})$ ) shows least amount of total protein content. It is evident from the table that the total protein content was significantly more in resistant genotypes than in susceptible genotypes respectively.

\section{Tannins}

The both resistant and susceptible genotypes shows significant difference in tanin content with respect to different stages of crop growth and with severity of disease (TABLE-3.)At 30DAS among resistant genotypes the tannin content was observed maximum in case of Hema $(2.6 \mathrm{mg} /$ dry wt) compared with Nithyashree $(1.8 \mathrm{mg} / \mathrm{dry}$ wt $)$ and in case of susceptible varities the $219 \mathrm{~J}(1.6 \mathrm{mg} / \mathrm{dry} \mathrm{wt})$ Shows higher amount of tannin as compared with CM-202 $(1.3 \mathrm{mg} / \mathrm{dry}$ wt $)$ The amount of tannin was increased significantly between 60DAS and 90DAS in both resistant and susceptible genotypes with the disease progress. The maximum mean content of tannin was observed in resistant genotypes 
Hema (3.6 mg/dry wt) followed by Nithyashree $(2.6 \mathrm{mg} / \mathrm{dry} \mathrm{wt})$ the lowest mean content was observed in susceptible genotypes $219 \mathrm{~J}(2.5 \mathrm{mg} / \mathrm{dry} \mathrm{wt})$ followed by CM-202(1.86 mg/dry wt) the mean tannin content was observed maximum in resistant genotypes as compared with susceptible genotypes.

\section{Total phenol}

The both resistant and susceptible genotypes shows significant difference in total phenol content with respect to different stages of crop growth and with severity of disease(Table4). At 30 DAS the total phenol content was more in resistant genotype i,e, Nithyashree $(0.77 \mathrm{mg} /$ dry wt) followed by Hema (0.63 mg/dry wt) And among susceptible genotypes the maximum phenol content was observed in CM-202 (0.37 mg/dry wt) followed by $219 \mathrm{~J}$ $(0.41 \mathrm{mg} /$ dry wt $)$ but there was significant increase over total phenol content among the genotypes with respect to increase in desease severity.

In susceptible genotypes the total phenol content was increased in duration of 60 to 90 DAS with respect to disease progress as compared with resistant genotypes. The total phenol content was maximum im 219J (1.33 mg/dry wt) followed by CM-202 (1.12mg/ dry wt) when observed at 90DAS and in case of resistant genotypes the maximum total phenol content was less as compared with susceptible genotypes with respect to disease progress.

Among all the genotypes the genotypes 219J $(0.86 \mathrm{mg} / \mathrm{dry} \mathrm{wt})$ shows maximum phenol content and the genotype Hema $(0.69 \mathrm{mg} / \mathrm{dry}$ wt) shows least amount of total phenol content. It is evident from the table that the total phenol content was significantly more in susceptible genotypes than in resistant genotypes.
In recent years, it is becoming increasingly evident that several natural and induced defence mechanisms operate in host plants against different diseases. One such defence mechanism is the presence of certain compounds inhibitory to the pathogen. Sometimes, the host plant is induced to synthesize these compounds on infection. Analysis of biochemicals in selected resistant and susceptible genotypes was carried out at three different growth stages to understand their role in resistance / susceptibility to turcicum leaf blight pathogen.

\section{Phenols}

The biochemical components present in plants imparts resistance against several diseases among that phenolics have been found to play an important role in determining resistance or susceptibility of a host to parasitic infection.

From the present investigation, it was observed that the total phenols were higher in resistant genotypes Nithyashree and Hema than that of susceptible genotypes CM-202 and 219J at 30 DAS before inoculation of fungus. The similar findings were observed by Sharma et al., (1992) reported that phenol concentration was less in susceptible genotypes as compared with resistant genotypes..Further observation when taken after 60 DAS and 90 DAS reveals that increase in concentration of phenol at different crop growth stages and with disease progress in both susceptible genotypes and with resistant genotypes. This was confirmation with findings of Sharma (1980) reported that the activity of enzyme phenyalanine ammonia lyase (PAL) in maize leaves inoculated with the fungus Helimenthosporium maydis, Nishikado And Miyake.

\section{Sugars}

In the present investigation, the resistant 
genotypes of maize, Nithyashree and Hema exhibited more reducing sugar content when compared with the susceptible genotypes, CM-202 and 219J. We could notice that there was decrease in the reducing sugar content in the susceptible genotypes which was ranging form 42.80 per cent to 43.36 per cent. i.e. all most three to four times reduction.

High amount of reducing sugar content in resistant genotypes and less in susceptible genotypes could be either due to,

i) Response of the host to infection resulting in increase in reducing sugar.

ii) Part of that may be utilized by the pathogen.

iii) Interference by the pathogen in the amylolytic activity.

Further, observations revealed that there was reduction in total, reducing and non-reducing sugar due to infection in both resistant and susceptible genotypes Irrespective of genotypes there was reduction in the reducing sugar content from 31.08 per cent to 9.63 per cent (at 30 DAS and 60 DAS respectively These results are in conformity with the reports of Ramdayal and Joshi (!968), in barley against leaf spot pathogen, Mandokhot et al., (1979) and Levy and Cohen (1984) in case of maize against turcicum blight and Subramanyam et al., (1990) in wheat against Exerohilum hawaiiensis. Sugars act as precursor for synthesis of phenolics, phytoalexins, lignin and cellulose which play an important role in defence mechanism of plants against invading pathogens. In the present investigation also resistant genotypes recorded higher sugars and these results corroborate the findings of Tripati and Chiranjeevi (1977); Naik et al., (1981) and Basarkar et al., (1988) in foliar disease resistant sorghum genotypes. Overall, high sugar content in resistant maize genotypes may be responsible for lower development of the leaf blight.

\section{Total protein}

In the present findings, mean total protein content was more in resistant genotypes than the susceptible genotypes. We could notice an increase in the protein content at 60 and 90 DAS when compared the resistant genotypes with susceptible genotypes. This result is in agreement with the findings of Malhotra (1993) and Malli et al., (2000). The protein content under both the genotypes (resistant and susceptible) increased from 30 DAS to 60 and 90 DAS. The rate of increase in the protein content in response to the disease infection was more in resistant genotypes.

In general, we could notice an increase in the protein content in response to infection at both the stages of crop growth ranging from 13.40 to 14.60 per cent.

Arjunan et al., (1976) who reported changes in protein content in sorghum leaves infected by $H$. tursicum. Its content in healthy and infected leaves was 0.31 and 0.39 per cent respectively in ten day old palnts and 0.24 and 0.02 per cent, respectively in sixty day old plants. In contrast to this Nandagopal (1995) reported that the wheat genotypes resistant to Exherohilum hawaiiensis (Bugnicourt) had lower crude protein content than that of the susceptible genotypes.

\section{Tannins}

Tannins have been shown to inhibit the growth of many fungi in vitro culture. Tannins, because of their ability to inhibits enzymes they are important in aiding the resistance of cells to attack by fungi and other pathogens. 
Table.1 Total sugar content in different maize genotypes

\begin{tabular}{|l|c|c|c|c|c|}
\hline \multirow{2}{*}{$\begin{array}{l}\text { Sl } \\
\text { No }\end{array}$} & \multirow{2}{*}{ Genotypes } & \multicolumn{4}{|c|}{$\begin{array}{c}\text { Total sugar content } \\
\text { mg/dry wt }\end{array}$} \\
\cline { 3 - 6 } & & $\mathbf{3 0}$ & $\mathbf{6 0}$ & $\mathbf{9 0}$ & Mean \\
& & DAS & DAS & DAS & \\
\hline $\mathbf{1}$ & CM-202 & 6.6 & 5.9 & 4.1 & 5.3 \\
\hline $\mathbf{2}$ & 219J & 5.2 & 4.5 & 3.5 & 4.4 \\
\hline $\mathbf{3}$ & NITHYASHREE & 18.6 & 16.2 & 13.2 & 16.0 \\
\hline $\mathbf{4}$ & HEMA & 16.1 & 15.3 & 11.1 & 14.1 \\
\hline
\end{tabular}

Table. 2 Total protein content in different maize genotypes

\begin{tabular}{|l|l|c|c|c|c|}
\hline \multirow{2}{*}{$\begin{array}{c}\text { Sl. } \\
\text { No. }\end{array}$} & \multirow{2}{*}{ Genotypes } & \multicolumn{4}{|c|}{ Total protein content } \\
& & $\mathbf{3 0}$ & $\mathbf{6 0}$ & $\mathbf{9 0}$ & Mean \\
\cline { 3 - 6 } & & 8.3 & 8.9 & 9.7 & 8.73 \\
\hline $\mathbf{1}$ & CM-202 & 9.4 & 10.3 & 11.8 & 10.5 \\
\hline $\mathbf{2}$ & 219J & 11.1 & 14.4 & 17.5 & 14.3 \\
\hline $\mathbf{3}$ & NITHYASHREE & 12.3 & 15.3 & 18.5 & 15.3 \\
\hline $\mathbf{4}$ & HEMA & & & & \\
\hline
\end{tabular}

Table.3 Tannin content in different maize genotypes

\begin{tabular}{|c|c|c|c|c|c|}
\hline \multirow{2}{*}{$\begin{array}{c}\text { Sl. } \\
\text { No. }\end{array}$} & \multirow{2}{*}{ Genotypes } & \multicolumn{4}{|c|}{ Tannins content } \\
& & $\mathbf{3 0}$ & $\mathbf{6 0}$ & $\mathbf{9 0}$ & Mean \\
\cline { 3 - 6 } & & 1.3 & 1.9 & 2.4 & 1.8 \\
\hline $\mathbf{1}$ & CM-202 & 1.6 & DAS & DAS & \\
\hline $\mathbf{2}$ & 219J & 1.6 & 2.5 & 3.4 & 2.5 \\
\hline $\mathbf{3}$ & NITHYASHREE & 1.8 & 2.6 & 3.1 & 2.6 \\
\hline $\mathbf{4}$ & HEMA & 2.6 & 3.7 & 4.7 & 3.6 \\
\hline
\end{tabular}

Table.4 Total phenol content in different maize genotypes

\begin{tabular}{|c|c|c|c|c|c|}
\hline \multirow{2}{*}{$\begin{array}{c}\text { Sl. } \\
\text { No. }\end{array}$} & \multirow{2}{*}{ Genotypes } & \multicolumn{4}{|c|}{ Total phenol content } \\
& & 30DAS & $\mathbf{6 0}$ & $\mathbf{9 0}$ & Mean \\
& & & DAS & DAS & \\
\hline $\mathbf{1}$ & CM-202 & 0.37 & 0.71 & 1.12 & 0.73 \\
\hline $\mathbf{2}$ & 219J & 0.41 & 0.84 & 1.33 & 0.86 \\
\hline $\mathbf{3}$ & NITHYASHREE & 0.77 & 0.87 & 0.91 & 0.85 \\
\hline $\mathbf{4}$ & HEMA & 0.63 & 0.69 & 0.75 & 0.69 \\
\hline
\end{tabular}


In present investigation both resistant and susceptible genotypes shows significant increase in tanin content with respect to different stages of crop growth and with severity of disease this corroborates with findings of Arora and Gandhi (1980) reported the effect of leaf spot disease on tannin content of sorghum varieties, S-36 and PC-16 and observed an increased tannin content in both the varieties as compared to control

In present investigation at 30 DAS among resistant genotypes the tannin content was observed maximum in case of Hema (2.6 $\mathrm{mg} /$ dry wt) compared with Nithyashree (1.8 $\mathrm{mg} /$ dry wt) And in case of susceptible varities the $219 \mathrm{~J}$ (1.6 mg/dry wt) Shows higher amount of tannin as compared with CM-202 (1.3 mg/dry wt).

The amount of tannin was increased significantly between 60DAS and 90DAS in both resistant and susceptible genotypes with the disease progress.

The maximum mean content of tannin was observed in resistant genotypes Hema (3.6 $\mathrm{mg} /$ dry wt) followed by Nityasree (2.6 $\mathrm{mg} /$ dry wt) the lowest mean content was observed in susceptible genotypes 219J (2.5 $\mathrm{mg} / \mathrm{dry}$ wt) followed by CM-202(1.86 mg/dry wt) the mean tannin content was observed maximum in resistant genotypes as compared with susceptible genotypes this corroborates with findings of several workers such as Ravi kumar et al., (1995) reported that resistant genotypes of finger millet had higher levels of tannin at all the four growth stages and it was negatively correlated with blast disease and Srinivas (2000) while studying biochemical action on resistance to Fusarium wilt of pigion pea observed that tannin content was more or less higher in resistant genotypes(ICPL-8863) and (ICPL88119) as compared to susceptible genotypes (TTB-7 andAKT-9221) at all DAI.

\section{Acknowledgement}

I humble place before the throne of the Almighty, my most sincere gratitude. His grace and tender mercies have renewed me every day, all the way on the journey through my life.

With immense pleasure and deep respect, I express my heartfelt gratitude to the chairman of my advisory committee Dr. K. T. Pandurange Gowda, Dean Agri, (Mandya), for his excellent guidance, constant support, close counsel and valuable suggestions throughout the period of my study. His enthusiasm, interest, concern, perfection and constructive criticism have always aroused my spirits to do more, to achieve higher.

The love, affection and patience of my family have been instrumental for me. Mere words cannot express my profound indebtness to my beloved parents Smt. Yashodha and Shri L..Eranna for filling my life with laughter and happiness beyond measure.

\section{References}

Anonymous, 2012, 56nd Annual Progress Report, All India Co-ordinated Maize ResearchProject, Directorate Of Maize Research, New Delhi, pp. 32.

Arora, Y.K. and Wagle, D.S., 1985, Interrelationship between peroxidase, polyphenol oxidase activities and phenolic content of wheat to resistance to loose smut. Biochemistry Physiology Pflanzen.,180: 7580.

Basarkar, P. W., Shivanna, H. and Joshi, V. R., 1988, Biochemical parameters of different sorghum leaves at 50 per cent anthesis. Sorghum Newsletter, 31 : 36 .

Bashan, Y., 1986, Phenols in cotton seedlings resistant and susceptible to Alternaria macrospora. Journal of Phytopathology, 116(1): 1-10.

Bhatia, I. S., Uppal, D. S. and Bajaj, K. C., 1972, 
Study of phenolic contents of resistant and susceptible varieties of tomato Lycopersicon esculentum in relation to early blight disease. Indian Phytopathology, $25: 231-235$.

Bosewell, J. G., 1963, Plant phenol oxidases and their relation to other oxidase systems in plants. In : Enzyme chemistry of phenolic compounds. (Ed.) Pridham, J. B., The McMillan Company, New York, pp. 280.

Chakrabarty, P.K., Mukewar, P.M., Shoe Raj and Sravan Kumar, V., 2002, Biochemical factors governing resistance in diploid cotton against grey mildew. Indian Phytopathology, 55(2): 140-146.

Chimmad, V.P., Panchal, Y.C., Chimmad, B.V. and Basarkar, P.W., 1998, Leaf reddening in cotton genotypes VI. Changes in Phenylalanine ammonia lyase (PAL), Tyrosine ammonia lyase (TAL) activities and free phenols. Karnataka J of Agric Sci, 11(4): 908-915.

Dharanendra Swamy, S., 2003, Studies on turcicum leaf blight of maize caused by Exserohilum turcicum. M.Sc(agri) Thesis, Univ. Agril. Sci., Dharwad, Karnataka,India.

Farkas, G. L. and Kiraly, Z., 1962, Role of phenolic compounds in the physiology of plant diseases and disease resistance. Phytopathology Zeitschrift, 44 : 105 - 150.

Guleria, S., Paul, B. and Bajaj, K. L., 1997, Biochemical changes in powdery mildew (Erysiphe polygoni D.C.) resistant and susceptible cultivars of pea (Pisum sativum L.) Plant Disease Research.12 : 185 - 188.

Gupta, S. K., Gupta, P. P. and Kaushik, C. D., 1995, Changes in leaf peroxidase, polyphenol oxidase, catalase and total phenols due to Alternaria leaf blight in Brassica species. Indian Journal of Mycology and Plant Pathology, 25(3) : 175 - 180.

Harlapur, S. I., 2005, Epidemiology and management of turcicum leaf blight of maize caused by Exserohilum turcicum (Pass) Leonard and Suggs., Ph. D. Thesis, univ. Agril.Sci., Dharwad, Karnataka, India. .

Harlapur, S. I., Mruthunjaya, C. W., Anahosur, K. H. and Muralikrishana, S., 2000, A report onsurvey and surveillance of maize diseases in north karnataka. Kar. J. Agric. Sci, 13(3): 750-751.

Harlapur, S. I., Kulkarni, M.S., Yeshoda hegde and Srikant kulkarni, 2007, Variability in Exserohilum turcicum (Pass) Leonard and Suggs., causal agents of turcicum leaf blight of maize. Kar. J. Agric. Sci, 20 (3): 665-666.

.Horsfall, J. G. AND Dimond, A. E, 1957, Interactions of tissue sugar, growth substances and disease susceptibility. Z Pflanzekrankh Pflenzenschutz, 64: 415-421.

Jordhan, E.G., Perkins, J.M., Schalf, R.A. and Pederson, W.L., 1983, Occurrence of race 2 of E.turcicum on corn in the central and eastern united states. Plant Dis, 67:1163-1165.

Kachapur, M. R., and Hegde, R.K., 1988, Studies on turcicum leaf blight caused by Exserohilum turcicum with special reference to crop loss assessment. pl. Path.News, L, 6: 33-35.

Kalappanavar, I. K. and Hiremath, R. V., 2000, Biochemical factors for multiple resistance to foliar diseases of sorghum. Madras Agricultural Journal, 87 : $66-70$.

Kalpana, Y. M. and Ganga, R. S., 2006, Role of phenolic compounds in sheath blight resistance in rice. Indian Journal of Mycology and Plant Pathology, 21: 205-206.

Kiraly, Z. and Farkas, G. L., 1962, Relation between phenol metabolism and stem rust resistance in wheat. Phytopathology, 52: 657 $-664$.

Krog, N. E., Tourneau, D. L. and Hart, H., 1961, The sugar content of wheat leaves infected with stem rust. Phytopathology, $51: 75-77$.

Kuc, J., 1964, Phenolic compound and disease resistance in plants. In: Phenolics in Normal and Diseased Fruits and Vegetables (Ed.), Reuneckles, V. C., pp. 63-81.

Levy, T. and Cohen, Y., 1984, A negative association between leaf sugar content and the development of northern leaf blight lesions in sweet corn. Physiological Plant Pathology, 24 : $134-138$.

Lowry, O. H., Rosebrough, Fan, A. L. and Randall, R. J., 1951, Protein measurement with folin phenol reagent. Journal of Biological Chemistry, 193: 265- 275.

Luthra, Y. D., Joshi, U. M., Gandhi, S. K., and Arora, S. K., 1988a, Biochemical alterations in downy mildew infected lucerne leaves. Indian Phytopathology, $41: 100$.

Malli,.2000 Effect of planting date and development of yellow mosaic virus on biochemical constuants of mothbean genotype 
Indian phytopathology -53:379-383.

Malhotra, S. K., 2009, Biochemical components of tomato genotypes in relation to Fusarium wilt. Indian Journal of Mycology and Plant Pathology, 18: 221 - 222.

Mandokhot, A. M., Singh, D. P., Basu chaudhary, K.C. and Singh, J. N., 1979, Chemical changes in maize leaves in response to leaf spot pathogens. Indian Phytopathology, 32 : $658-660$.

Nandagopal, N., 1995, Morpho - physiological, histopathological and biochemical changes in Triticum durum Desf. Varieties of wheat infected by Exerohilum hawaiiensis (Bugnicourt) Subram and Jain Ex. Mb. Ellis A causal agent of leaf blight. M.Sc.(Agri.) Thesis, University of Agricultural Sciences, Dharwad, pp. 66-68

Owens, L. D., 1953, Toxins in plant disease structure and mode of action. Science, 165 : $18-25$.

Pandurangegowda, K.T., Jayaramagowda, B. and Rajashekharaiah, 1989,Variability in the incidence of turcicum leaf blight of maize in southern karnataka. Current Research, 18: 115-116.

Prasad, M. N., Kotireddy, M. and Purushothaman, D., 1972, A study on certain biochemical and physiological changes in resistant and susceptible rice varieties following blast and bacterial blight pathogens. Final Technical Report of the Project :Biochemistry of Specificity of Pathogens, pp. 267.

Ramdayal and Joshi, M. M., 1968, Post infection changes in the sugar content of leaf spot infected barley. Indian Phytopathology, 21 : $221-222$.
Reddy, A. G. R., 1976, Studies on biochemical factors associated with resistance to leaf blight caused by Drechslera turcica (Pass.) Subram and Jain in Sorghum (Sorghum vulgare). Ph.D. Thesis, University of Agricultural Sciences, Bangalore. pp- $84-86$

Reddy, M. N., 1984, Changes in phenolic acids in groundnut leaves infected with rust. Phytopathology, $110: 78-81$.

Sadasivam, S. and Manickam, A., 1996, Biochemical Methods. II Edition, New Age International (P) Ltd., New Delhi, pp. 256.

Shaner, G., 1973, Reduced infectability and inoculum production on factors of slow mildewing in knox wheat. Phytopathology, 63: 1307-1311.

Sharma,.1980 Biochemistry of host parasite interaction, studies on maize infected to H.maydis university of agri, technology157BP,Phd Thesis, G.B.Panth..

Sharma, R.C. and Payak, M.M., 1990, Durable resistance in the maize inbred lines. Theor.Appl. Genet., 80: 542-544.

Sharma, J. R., Mishra, B. and Krishna jha, 1992, Biochemical relationship in resistant and susceptible cultivars with turcicum leaf blight disease in maize. Indian Phytopathology, 45: $241-243$

Walker, J. C. and Link, K. P., 1935, Toxicity of phenolic compounds to certain onion bulb parasites. Botanical Gazette, 96: 468-484.

Zuber, M. and Manibhushan RAO, K., 1984, Changes in phenolics and enzymes of phenol metabolism in sheath blight disease of rice caused by Rhozoctonia solani.. Act Phytopathology Academy of Science, Hungary, $19: 251-262$.

\section{How to cite this article:}

Jagadeesh, E., K. T. Pandurange Gowda and Narayana Swamy, K. C. 2020. Biochemical Basis of Resistance to Turcicum Leaf Blight of Maize caused by Exserohilum turcicum (Pass.) Leonard and Suggs. Int.J.Curr.Microbiol.App.Sci. 9(03): 1958-1968.

doi: https://doi.org/10.20546/ijcmas.2020.903.228 